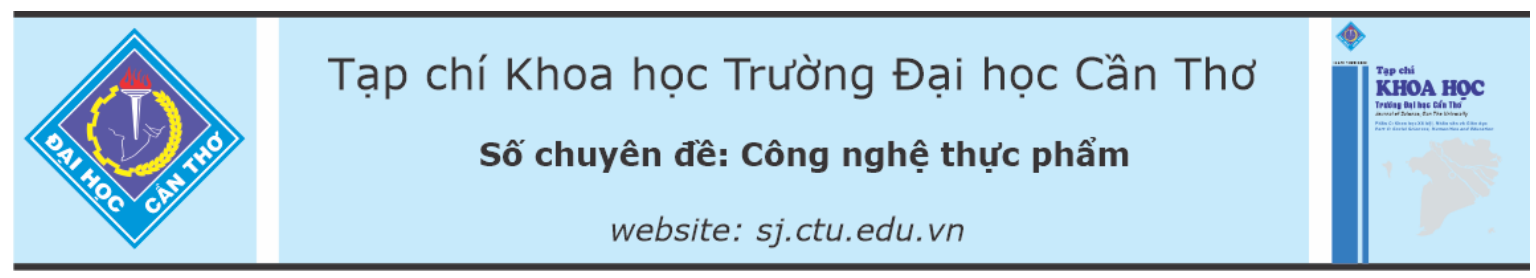

DOI:10.22144/ctu.jsi.2021.001

\title{
ĐÁNH GIÁ CHÂT LƯợNG KHÔ CÁ LÓC THEO TIÊU CHUẨN VIẸT NAM
}

\author{
Trần Bạch Long ${ }^{1,2 *}$ và Nguyễn Văn Mười ${ }^{2}$ \\ ${ }^{1}$ Nghiên cưu sinh ngành Công nghệ Sinh học, Viện NC\&PT Công nghệ Sinh học, Truờng Đại học Cần Tho \\ ${ }^{2}$ Bộ môn Công nghệ Thưc phẩm, Khoa Nông nghiệp, Truòng Đại học Cần Tho \\ "Người chịu trách nhiệm về bài viết:Trần Bạch Long (email: tblong@ctu.edu.vn)
}

\section{Thông tin chung:}

Ngày nhận bài: 23/02/2021

Ngày nhận bài sưa: 10/03/2021

Ngày duyệt đăng: 28/04/2021

\section{Title:}

Quality assessment of dried snakehead fish based on Viet Nam standards

\section{Tù khóa:}

Cảm quan, chất luợng, khô cá lóc, nhiệt độ bảo quản

\section{Keywords:}

Dried snakehead fish, quality, storage temperature, sensory

\begin{abstract}
The study was conducted to evaluate the quality of dried snakehead fish (Channa striata) stored at different temperatures and to compare the quality of experimental dried fish with commercial dried fish products. The results showed that low temperature limited the lipid oxidation to extend storage time, quality assurance, and food safety of dried fish products. The dried snakehead fish was still ensured about microbial standard, heavy metal, and $a_{w}$ after 12-week storage at room temperature $\left(28-30^{\circ} \mathrm{C}\right)$, 32-week storage at cold temperature $\left(0-4^{\circ} \mathrm{C}\right)$, and 48 -week frozen storage $\left(-18\right.$ to $\left.-20^{\circ} \mathrm{C}\right)$. Besides, the quality and sensory of the dried snakehead fish product in this study were higher than commercial dried fish, as well as met the standards of TCVN 5649: 2006 and TCVN 10734: 2015.
\end{abstract}

\section{TÓM TẮT}

Nghiên cưu được thực hiện nhằm đánh giá chất luợng sản phẩm khô cá lóc (Channa striata) được bảo quản ở các nhiệt độ khác nhau và nhằm so sánh chất luợng khô cá lóc nghiên cứu và các sản phẩm khô cá lóc trên thị truờng. Kết quả cho thấy việc sủ dụng nhiệt độ thấp làm hạ chế sự oxy hóa lipid giúp kéo dài thời gian bảo quản, đảm bảo chất luợng và an toàn vệ sinh thực phẩm của khô cá. Khô cá lóc vẫn đảm bảo an toàn về chỉ tiêu vi sinh, kim loại nạng và độ hoạt động của nuoớc sau 12 tuần bảo quản ở nhiệt độ phòng $\left(28-30^{\circ} \mathrm{C}\right)$, 32 tuần bảo quản ở nhiệt độ lạnh $\left(0-4^{\circ} \mathrm{C}\right)$ và 48 tuần trũ đông (-18 đến $-20^{\circ} \mathrm{C}$ ). Bên cạh đó, sản phẩm khô cá lóc nghiên cúu có chất luợng và cảm quan cao hơn sản phẩm khô trên thị truờng, đồng thời đáp úng đurợc TCVN 5649:2006 và TCVN 10734:2015.

\section{GIỚI THIẸU}

Cá lóc là một trong những loài cá đặc trưng ở vùng Đồng bằng sông Cửu Long,có 4 loài gồm: cá lóc đen (Channa striata), cá chành dục (Channa gachua), cá lóc bông (Channa micropeltes) và cá dầy (Channa lucia) (Mai Đình Yên \& ctv., 1992; Nguyễn Văn Hảo, 2005; Tran et al., 2013 trích dẫn bởi Hồ Mỹ Hạnh \& Bùi Minh Tâm, 2015; Trương
Thủ Khoa \& Trần Thị Thu Hương, 1993), hai loài Channa striata và Channa micropeltes chiếm chủ yếu trong cơ cấu nuôi ở khu vực Đồng bằng sông Cửu Long (Lê Xuân Sinh \& Đố Minh Chung, 2010). Trong đó, cá lóc đen (Channa striata Bloch, 1973) là loài cá quen thuộc đối với người dân, được nuôi phổ biến không chỉ bởi đặc điểm dễ nuôi, chất lượng thịt ngon mà còn do giá trị dinh dưỡng cao và phù 
hợp với thị hiếu người tiêu dùng. Tuy nhiên, ngay sau khi chết, biến đổi hóa lý, hoạt động của enzyme phân giải protein và sự oxy hóa lipid làm giảm chất lượng nguyên liệu (Ceballos, 2012). Việc ướp muối và sây khô là các phương pháp bảo quản thường được sử dụng ở hầu hết các quốc gia đang phát triển (Akintola et al., 2013). Khô cá lóc có vị ngon đặc trưng và từ lâu rất được người dân ưa chuộng, được sản xuất đại trà ở nhiều nơi, đặc biệt là vùng An Giang và Cà Mau. Tuy nhiên, quy mô sản xuất chưa lớn và quy trình công nghệ chưa ổn định, do đó thời gian bảo quản còn khá ngắn (tối đa 3 tháng ở nhiệt độ mát), không thích hợp để phân phối sản phẩm đến các thị trường giàu tiềm năng ở xa. Mặt khác, các sản phẩm khô trên thị trường đều có đặc điểm chung là có độ mặn cao, độ ẩm thấp nhằm ngăn cản các hư hỏng xảy ra, tuy nhiên giá trị cảm quan của sản phẩm giảm đáng kể, mất vị đặc trưng của thịt cá. Việc sử dụng các chất bảo quản không rõ nguồn gốc và không kiểm soát liều lượng cũng là vấn đề cần phải quan tâm (Nguyễn Văn Mười \& Trần Thanh Trúc, 2016). Nitipong \& ctv. (2014) cho thấy việc kết hợp chất chống oxy hóa và bảo quản nhiệt độ thấp giúp hạn chế quá trình oxy hóa trong sản phẩm cá lóc sấy khô. Do đó, việc điều chỉnh nhiệt độ bảo quản được xem là biện pháp ức chế hoạt động của vi sinh vật từ đó giúp ngăn cản các biến đổi chất lượng trong quá trình bảo quản.

\section{PHƯƠNG PHÁP NGHIÊN CÚU}

\subsection{Nguyên liệu}

Cá lóc (Channa striata) được thu mua từ vùng nuôi huyện Trà Cú, tỉnh Trà Vinh. Khối lượng dao động trong khoảng từ 500-800 g. Cá khi thu mua được giữ sống, khỏe mạnh, nguyên vẹn (không trầy xước), không có khuyết tật, không nhiễm bệnh hay ký sinh trùng, đạt các yêu cầu dùng cho quá trình chế biến thực phẩm. Cá lóc sau khi mua được giữ sống trong thùng nhựa có chứa nước, thời gian vận chuyển về phòng thí nghiệm tối đa trong 3 giờ. Khi cá được chuyển đến phòng thí nghiệm (Bộ môn Công nghệ thực phẩm, Khoa Nông nghiệp, Trường Đại học Cần Thơ), cá được giữ ổn định trong bể nước ít nhất 1 giờ trước khi xử lý và tiến hành phân tích, khảo sát tiếp theo.

Cá lóc được cân khối lượng trước khi làm ngất, cắt tiết và xả máu trong nước (thời gian xả máu 10 phút ở nhiệt độ phòng để đảm bảo loại máu hoàn toàn). Cá sau khi cắt tiết được chuyển sang đánh vảy, bỏ mang, nắp mang, nội tạng và đầu (Tran Bach Long et al., 2017). Cá sau khi xử lý được ngâm trong dung dịch muối $\mathrm{NaCl}$ ở nồng độ $12 \%$, thời gian ngâm là 3 giờ, tỷ lệ cá : dung dịch là 1:1 (Trần Bạch
Long \& ctv., 2019). Cá sau khi ngâm muối vớt ra, để ráo, ngâm phụ gia (glycerol 3\%, sorbitol 4\%, acid ascorbic $0,04 \%$ ) trong thời gian 1 giờ (Long et al., 2020). Sau đó tiến hành sấy cá lóc ở nhiệt độ $50 \pm 3^{\circ} \mathrm{C}$ với lưu lượng không khí nóng $2 \mathrm{~m} / \mathrm{s}$ đến khi khô cá lóc đạt độ ẩm 20\% (Trần Bạch Long và ctv, 2020). Sản phẩm khô cá sau đó tiến hành bao gói trong bao bì PA có độ chân không $80 \%$.

\subsection{Phương pháp nghiên cứu}

\subsubsection{Bố trí thí nghiệm}

\section{Thí nghiệm 1: Đánh giá sự ổn định chất lượng của khô cá lóc ở các điều kiện bảo quản khác nhau}

Cá lóc sấy khô tiến hành bảo quản ở 3 mức nhiệt độ: nhiệt độ phòng $\left(28-30^{\circ} \mathrm{C}\right)$, nhiệt độ lạnh $\left(0-4^{\circ} \mathrm{C}\right)$ và lạnh đông $\left(-18\right.$ đến $\left.-20^{\circ} \mathrm{C}\right)$. Định kỳ theo dõi sự thay đổi chất lượng sản phẩm theo thời gian bảo quản (đối với sản phẩm bảo quản ở nhiệt độ thường định kỳ 1 tuần/lần, bảo quản nhiệt độ lạnh 2 tuần/lần, trữ đông 4 tuần/lần). Kết quả được đánh giá qua mức độ tăng ẩm, sự thay đổi độ hoạt động của nước và mật số nấm mốc trong sản phẩm. Thành phần dinh dưỡng, vi sinh và kim loại nặng của khô cá sau khi bảo quản được gởi mẫu đến cơ quan kiểm định độc lập để phân tích.

\section{Thí nghiệm 2: So sánh các chỉ tiêu hóa lý của khô cá lóc nghiên cứu với sản phẩm trên thị trường}

Mục tiêu là so sánh chất lượng và sự chấp nhận của người tiêu dùng đối với sản phẩm khô cá lóc nghiên cứu và sản phẩm thị trường (chú ý chọn lựa các mẫu khô có độ ẩm xấp xỉ $20 \%$, theo TCVN 10734:2015). Ba mẫu khô cá lóc sử dụng để khảo sát gồm (1) Khô cá lóc chế biến theo phương thức được nghiên cứu, (2) Mẫu 1 - Mẫu thương mại (được phân phối ở siêu thị, sản xuất ở Đồng Tháp) (3) Khô cá lóc cơ sở 2 (tại Chợ Mới, An Giang). Khối lượng $1 \mathrm{~kg} / \mathrm{mẫu}$ khô. Tiến hành phân tích thành phần dinh dưỡng, vi sinh, kim loại nặng theo TCVN 10734:2015 và TCVN 5649:2006, đánh giá cảm quan.

\subsubsection{Phuoong pháp phân tích}

- Độ ẩm (\%): Sấy ở $105^{\circ} \mathrm{C}$ đến khối lượng không đổi (TCVN3700:1990).

- Độ hoạt động của nước được kí hiệu là $\mathrm{a}_{\mathrm{w}}$ hay phần trăm cân bằng ẩm $(\% \mathrm{ERH})$. Để đo được $\mathrm{a}_{\mathrm{w}}$ thì một mẫu thử của sản phẩm được đặt trong một bình kín cách ly mẫu thử với môi trường bên ngoài. Một thiết bị cảm biến đặt trong bình sẽ đo độ ẩm tương đối của không khí phía trên thực phẩm. Sau một 
khoảng thời gian đơn vị đo lường sản phẩm tương đối đạt giá trị không đổi vì có sự thiết lập cân bằng giữa không khí và thực phẩm. Đây gọi là \% $\mathrm{ERH}$ nếu nó được biểu diễn bởi phần trăm (0 đến 100\%) hoặc hoạt độ của nước nếu nó được biểu diễn trong khoảng giá trị từ 0 đến 1 .

- Hàm lượng $\mathrm{N}^{-\mathrm{NH}_{3}}(\mathrm{mg} \%)$ : Xác định theo TCVN 3706-90.

- Tổng số nấm men nấm mốc: Xác định theo TCVN 5649: 2006.

\subsubsection{Phương pháp đánh giá cảm quan}

Phuong pháp đánh giá các thuộc tính cảm quan của khô cá lóc

Đối với dòng sản phẩm này, do TCVN 10734: 2015 đã đề xuất phương thức đánh giá cảm quan, do đó, phương pháp đánh giá cảm quan được thực hiện theo 4 nhóm thuật ngữ cảm quan bao gồm màu sắc (đặc trưng cho sản phẩm), mùi, vị (đặc trưng cho sản phẩm, không có mùi vị lạ), trạng thái (độ đàn hồi, bề mặt khô, không dính ướt khi bảo quản ở nhiệt độ thường), ngoài ra còn có tính chất không có tạp chất lạ nhìn thấy bằng mắt và không có sự hiện diện của côn trùng vá xác côn trùng. Với 7 cảm quan viên được hướng dẫn để đánh giá sản phẩm khô cá với mức độ ưa thích theo cường độ mô tả về màu sắc, mùi vị và trạng thái (điểm từ 1 đến 5 theo thang điểm QDA được thiết lập).

Khảo sát thị hiếu người tiêu dùng đối với sản phẩm khô cá lóc nghiên cứu và so sánh với sản phẩm có sã̃n trên thị truờng

Sử dụng thang Hedonic với 9 điểm $(1=$ không thích vô cùng và $9=$ thích vô cùng, cùng với các mô tả trung gian giữa điểm 2 đến 8 ) (Villanueva \& Da Silva, 2009), số lượng cảm quan viên là 50 người được lựa chọn ngẫu nhiên để đánh giá sản phẩm khô cá lóc nghiên cứu và thị trường.

\subsubsection{Phuoong pháp thu nhận và xử lý số liệu}

Các thí nghiệm được bố trí hoàn toàn ngẫu nhiên với ba lần lặp lại. Số liệu được thu thập và xử lý bằng phần mềm thống kê Statgraphics Centurion 16.1 và phần mềm Microsoft Excel 2016. Phân tích phương sai ANOVA và kiểm định LSD, Duncan để kết luận về sự sai khác giữa trung bình các nghiệm thức. Kết quả đánh giá cảm quan được xử lý bằng phần mềm thống kê XLSTAT 2018.

\section{KẾT QUẢ VÀ THẢO LUẬN}

\section{1. Ảnh hưởng của nhiệt độ bảo quản đến chất lượng của khô cá lóc}

\subsubsection{Mức độ tăng ẩm và sự thay đổi độ hoạt động của nuớc của khô cá lóc theo thời gian bảo quản}

Mối quan hệ giữa độ hoạt động của nước và độ ẩm trong thực phẩm được các chuyên gia khoa học thực phẩm sử dụng để phát triển sản phẩm (Abbas et al., 2009) cũng như dự đoán sự biến đổi chất lượng trong thời gian bảo quản. Sự biến đổi hai thông số này trong quá trình bảo quản khô cá lóc ở 3 điều kiện nhiệt độ tồn trữ khác nhau được thể hiện qua Hình 1 và Hình 2.

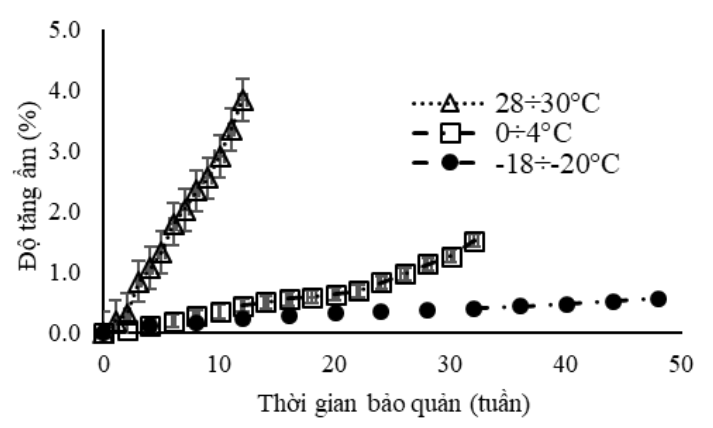

Hình 1. Ảnh hưởng của nhiệt độ bảo quản đến độ tăng ẩm $(\%)$ của khô cá lóc

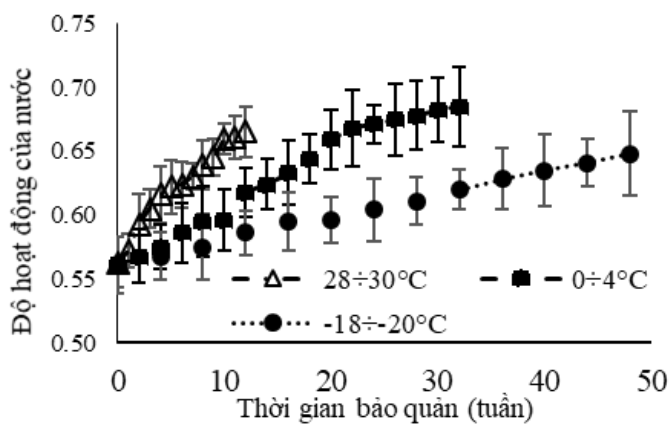

Hình 2. Sự thay đổi độ hoạt động của nước $\left(\mathrm{a}_{\mathrm{w}}\right)$ của khô cá lóc trong quá trình bảo quản

Kết quả phân tích và đo đạc cho thấy rằng độ ẩm và độ hoạt động của nước ở khô cá lóc đều tăng dần theo thời gian bảo quản, tuy nhiên mức độ tăng ẩm là đáng kể và rõ rệt nhất ở nhiệt độ bảo quản cao $\left(28-30^{\circ} \mathrm{C}\right)$. Điều này có thể là do môi trường không khí có độ ẩm tương đối cao, không có sự cân bằng với khô cá lóc có độ hoạt động của nước thấp $(0,563$ 
ở thời điểm ban đầu trước khi bảo quản) và thời gian bảo quản dài dẫn đến thấm hơi nước qua bao bì. Tuy nhiên, nhiệt độ bảo quản thấp có tác động tích cực đến việc ngăn cản sự mất ẩm. Trong quá trình bảo quản, mức độ tăng ẩm ở mẫu trữ đông (-18 đến $20^{\circ} \mathrm{C}$ ) là thấp nhất (chỉ tăng $0,57 \%$ ) sau 48 tuần, trong khi ở điều kiện nhiệt độ $28-30^{\circ} \mathrm{C}$ mức độ tăng ẩm lên đến $3,84 \%$ chỉ sau 12 tuần và tăng $1,52 \%$ sau 32 tuần bảo quản ở điều kiện tồn trữ lạnh $0-4^{\circ} \mathrm{C}$. Theodore and Altunakar (2008) cho rằng tính chất vật lý của thực phẩm trên thực tế là một sự bất ổn về nhiệt động học vì sự biến đổi hóa học hoặc độ hoạt động của nước. Do đó, độ ẩm của sản phẩm thay đồi dẫn đến độ hoạt động của nước thay đổi (Hình 2). Độ hoạt động của nước ban đầu của khô cá lóc trong khoảng 0,561 đến 0,563 điều này rất có lợi trong quá trình bảo quản, nhất là về mặt vi sinh. Tuy nhiên, sự gia tăng độ ẩm cũng kéo theo sự tăng $\mathrm{a}_{\mathrm{w}}$ của khô cá lóc (mức tăng xấp xỉ 0,1 - thể hiện qua giá trị độ hoạt động của nước sau thời gian bảo quản tối đa là 0,648 đến 0,685 ). Độ hoạt động của nước thay đổi dẫn đến xảy ra phản ứng hóa học, làm giảm thời hạn sử dụng (Kapsalis, 1981). Esener et al.. (1981) đã cho thấy điều này đối với sự phát triển của vi sinh vật, trong khi Barden (2004) đã chứng minh điều này đối với quá trình oxy hóa lipid. Mặc dù vậy, mức $\mathrm{a}_{\mathrm{w}}$ vẫn thấp hơn 0,75 là điều kiện an toàn giúp ức chế sự phát triển của nấm mốc và một số vi khuẩn ưa mặn có thể phát triển ở nhiệt độ phòng (Potter \& Hotchkiss, 1995). Kilic (2009) cũng cho rằng cá khô có độ ẩm $<25 \%$ và hoạt động của nước $<0,80$ đủ để ức chế sự phát triển của vi khuẩn có hại và đảm bảo an toàn cho sản phẩm.

\subsubsection{Sự thay đổi tổng số nấm men nấm mốc}

Từ kết quả phân tích sự hiện diện của tổng số nấm men, nấm mốc trong khô cá lóc (Hình 3 ) có thể nhận thấy tổng số nấm men, nấm mốc vẫn hoạt động và tăng trưởng trong quá trình bảo quản, ngay cả ở điều kiện nhiệt độ bảo quản rất thấp $\left(-18\right.$ đến $\left.-20^{\circ} \mathrm{C}\right)$ và độ hoạt động của nước trong sản phẩm thấp (Hình 2).

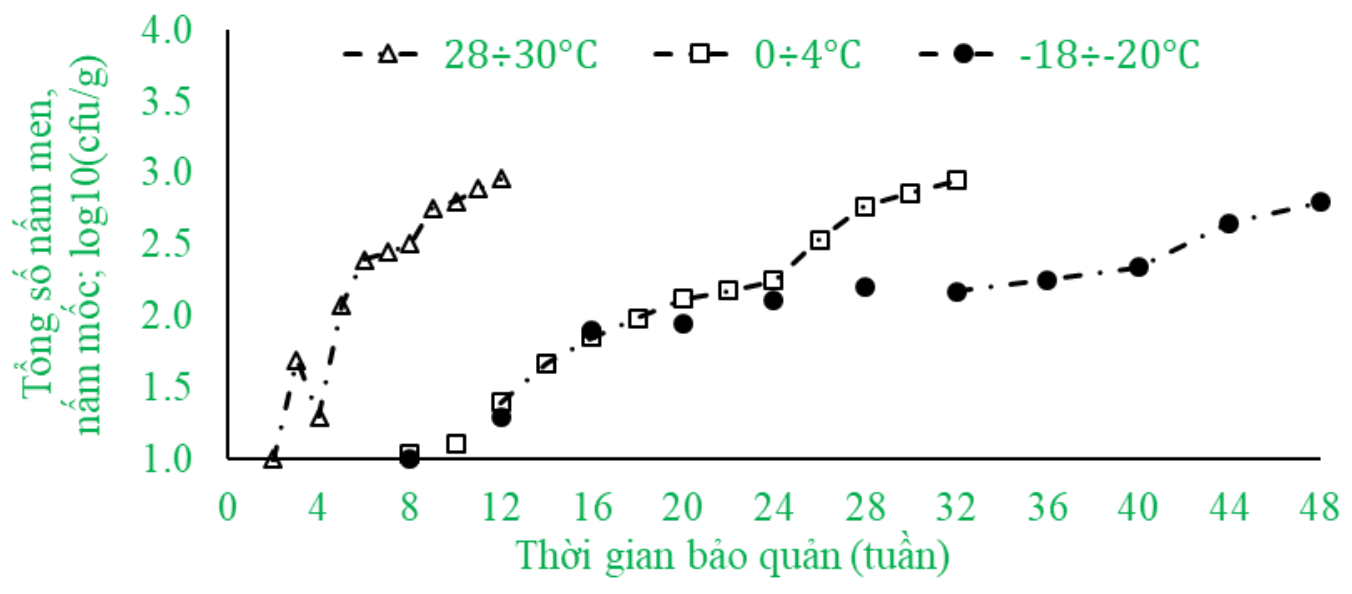

\section{Hình 3. Sự biến động tổng số nấm men, nấm mốc trong khô cá lóc theo thời gian bảo quản}

Sự gia tăng mật số tổng số nấm men, nấm mốc trong sản phẩm là không nhiều và không rõ nét. Nhìn chung, sự hiện diện của tổng số nấm men, nấm mốc trong khô đều dưới mức tối đa cho phép là $10^{3}$ cfu/g (theo tiêu chuẩn TCVN 5649: 2006, QĐ 47/2006 và QCVN 8:3).

\subsubsection{Thành phần dinh dương, vi sinh và kim loại trong khô cá lóc sau quá trình bảo quản}

Kết quả thành phần dinh dưỡng, các chỉ tiêu hóa lý, vi sinh được tồng hợp ở Bảng 1 và Bảng 2 cho thấy điều kiện bao gói bằng bao bì $\mathrm{PA}$ ở độ chân không $80 \%$ là điều kiện thích hợp để duy trì chất lượng khô cá lóc, thể hiện ở sự duy trì ổn định chất lượng theo tiêu chuẩn Việt Nam 10734: 2015, ngay cả sau thời gian bảo quản kéo dài. Kết quả phân tích cho thấy sản phẩm khô cá lóc có giá trị dinh dưỡng cao, thể hiện ở hàm lượng protein chiếm gần $60 \%$ tổng thành phần, lipid tương đối thấp và vị mặn hài hòa. Điều này cho thấy việc kiểm soát quá trình bảo quản tốt là điều kiện cần thiết để ngăn cản sự hư hỏng do phản ứng hóa học, vi sinh và enzyme. Trong phạm vi nghiên cứu, chất lượng sản phẩm vẫn được duy trì ổn định đến 12 tuần bảo quản ở nhiệt độ phòng $\left(28-30^{\circ} \mathrm{C}\right), 32$ tuần khi bảo quản ở nhiệt độ lạnh $\left(0-4^{\circ} \mathrm{C}\right)$ và đến 48 tuần khi tồn trữ lạnh đông $\left(-18\right.$ đến $\left.-20^{\circ} \mathrm{C}\right)$, thể hiện ở chỉ tiêu hóa lý, vi sinh và kim loại nặng. 
Bảng 1. Thành phần hóa học của khô cá lóc sau thời gian bảo quản tối đa ở nhiệt độ khác nhau

\begin{tabular}{|c|c|c|c|c|c|}
\hline Chỉ tiêu & $\begin{array}{l}\text { Ban } \\
\text { đầu }\end{array}$ & $\begin{array}{r}\text { Sau } 12 \text { tuần } \\
\text { bảo quản ở } \\
28-30^{\circ} \mathrm{C} \\
\end{array}$ & $\begin{array}{r}\text { Sau } 32 \text { tuần } \\
\text { ở }^{0} 0-4^{\circ} \mathrm{C}\end{array}$ & $\begin{array}{r}\text { Sau } 48 \text { tuần } \\
\text { trữ đông } \\
\left(-18 \text { đến }-20^{\circ} \mathrm{C}\right) \\
\end{array}$ & $\begin{array}{l}\text { Mức tối đa } \\
\text { theo TCVN }\end{array}$ \\
\hline Độ ẩm (\%) & 19,73 & $22,37 \pm 0,55$ & $21,79 \pm 0,23$ & $21,13 \pm 0,26$ & 20 \\
\hline Độ hoạt động của nước $\left(\mathrm{a}_{\mathrm{w}}\right)$ & 0,563 & $0,665 \pm 0,020$ & $0,685 \pm 0,031$ & $0,648 \pm 0,033$ & 0,75 \\
\hline Protein $(\%)$ & 58,57 & $56,45 \pm 1,09$ & $57,03 \pm 0,95$ & $57,54 \pm 0,95$ & \\
\hline Lipid (\%) & 6,73 & $5,87 \pm 0,46$ & $6,02 \pm 0,57$ & $6,23 \pm 0,25$ & \\
\hline $\mathrm{NaCl}(\%)$ & 6,05 & $5,87 \pm 0,37$ & $5,95 \pm 0,35$ & $6,03 \pm 0,28$ & \\
\hline Carbohydrate (\%) & 1,54 & $1,48 \pm 0,55$ & $1,52 \pm 0,22$ & $1,57 \pm 0,25$ & \\
\hline Peroxide (meq $/ \mathrm{kg}$ ) & 0,033 & $0,144 \pm 0,04$ & $0,161 \pm 0,021$ & $0,170 \pm 0,034$ & \\
\hline
\end{tabular}

Bảng 2. Chỉ tiêu kim loại và vi sinh vật trong sản phẩm khô cá lóc sau quá trình bảo quản

\begin{tabular}{|c|c|c|c|c|c|}
\hline Chỉ tiêu & $\begin{array}{l}\text { Ban } \\
\text { đầu }\end{array}$ & $\begin{array}{l}\text { Sau } 12 \text { tuần } \\
\text { bảo quản ở 28- } \\
30^{\circ} \mathrm{C} \\
\end{array}$ & 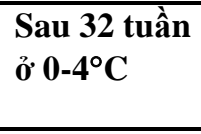 & $\begin{array}{l}\text { Sau } 48 \text { tuần } \\
\text { trữ đông } \\
\left(-18 \text { đến }-20^{\circ} \mathrm{C}\right)\end{array}$ & $\begin{array}{r}\text { Múc tối } \\
\text { đa theo } \\
\text { TCVN }\end{array}$ \\
\hline $\operatorname{Asen}(A s), m g / k g$ & 0,289 & $0,275 \pm 0,05$ & $0,264 \pm 0,04$ & $0,283 \pm 0,07$ & 1,0 \\
\hline Chì $(P b), m g / k g$ & KPH & $\mathrm{KPH}$ & $\mathrm{KPH}$ & $\mathrm{KPH}$ & 0,5 \\
\hline Thủy ngân (Hg), $\mathrm{mg} / \mathrm{kg}$ & KPH & $\mathrm{KPH}$ & $\mathrm{KPH}$ & $\mathrm{KPH}$ & 0,5 \\
\hline Cadimi $(C d), m g / k g$ & KPH & $\mathrm{KPH}$ & $\mathrm{KPH}$ & $\mathrm{KPH}$ & 0,1 \\
\hline TVKHK (cfu/g) & $2,0.10^{2}$ & $4,5 \times 10^{3}$ & $4,4 \times 10^{3}$ & $4,7 \times 10^{3}$ & $10^{6}$ \\
\hline E. $\operatorname{coli}(\mathrm{cfu} / \mathrm{g})$ & $<3$ & $<3$ & $<3$ & $<3$ & 10 \\
\hline S. aureus $(\mathrm{cfu} / \mathrm{g})$ & $<10$ & $<10$ & $<10$ & $<10$ & $10^{2}$ \\
\hline Cl. perfringens $(\mathrm{cfu} / \mathrm{g})$ & $<10$ & $<10$ & $<10$ & $<10$ & 20 \\
\hline Coliform $(\mathrm{cfu} / \mathrm{g})$ & $<10$ & $<10$ & $<10$ & $<10$ & $10^{2}$ \\
\hline Salmonella (/25g) & KPH & $\mathrm{KPH}$ & $\mathrm{KPH}$ & $\mathrm{KPH}$ & 0 \\
\hline V.parahaemolyticus (cfu/25g) & $\mathrm{KPH}$ & $\mathrm{KPH}$ & $\mathrm{KPH}$ & $\mathrm{KPH}$ & $10^{2}$ \\
\hline $\begin{array}{l}\text { TSBT nấm men, nấm mốc } \\
(\mathrm{cfu} / \mathrm{g})\end{array}$ & $<10$ & $9,0 \times 10^{2}$ & $8,9 \times 10^{2}$ & $9,2 \times 10^{2}$ & $10^{3}$ \\
\hline
\end{tabular}

(Nguồn: Kết quả được phân tích tại Trung tâm Kiểm định chất lự̛ng nông lâm thủy sản vùng 6-Nafiqad 6, KPH: không phát hiện, TCVN: tiêu chuẩn Việt Nam)

Kết quả phân tích chỉ số peroxide của sản phẩm cũng cho thấy có sự gia tăng đáng kể theo thời gian bảo quản, nhưng vấn trong giới hạn cho phép. Ở thời gian bảo quản tối đa đã đề xuất, các chỉ tiêu vi sinh cũng như kim loại nặng của khô cá lóc tương ứng 3 điều kiện nhiệt độ tồn trữ đều có giá trị dưới giới hạn cho phép của sản phẩm khô theo tiêu chuẩn Việt Nam (theo TCVN 5649: 2006 cho phép tổng vi khuẩn hiếu khí là $10^{6} \mathrm{cfu} / \mathrm{g}$ và tổng số bào tử nấm men - nấm mốc là $10^{3} \mathrm{cfu} / \mathrm{g}$ ). Kết quả phân tích cũng cho thấy có sự hiện diện của asen trong sản phẩm khô, điều này cũng thường gặp ở các sản phẩm thủy sản thông thường, đồng thời giá trị 0,264 $0,289 \mathrm{mg} / \mathrm{kg}$ là mức thấp, vẫn đảm bảo tiêu chuẩn. Nói cách khác, nhiệt độ bảo quản thấp kết hợp với việc sử dụng bao bì là điều kiện bảo quản được lựa chọn cho sự ổn định chất lượng của khô cá lóc.

\subsection{So sánh chất lượng khô cá lóc nghiên cứu và sản phẩm thương mại}

\subsubsection{Sụ thay đổi các chỉ tiêu hóa lý}

Mẫu khô nghiên cứu trong phòng thí nghiệm được chọn là mẫu đã bảo quản từ 3-5 tuần ở nhiệt độ phòng, đảm bảo cùng điều kiện về thời gian đối với các mẫu thị trường (không ghi cụ thể ngày sản xuất, chỉ đóng gói sau khi người tiêu dùng lựa chọn theo sở thích và đóng thời gian sử dụng). Các mẫu khô này có độ ẩm trước khi khảo sát lần lượt là $20,23 \pm 0,96 \%$ (mẫu nghiên cứu), 18,80 $\pm 1,13 \%$ (mẫu cơ sở 1 ) và $21,09 \pm 0,82 \%$ (mẫu cơ sở 2 ). Các chỉ tiêu hóa lý và vi sinh được phân tích để đánh giá và so sánh chất lượng của sản phẩm nghiên cứu với hai sản phẩm thương mại, thể hiện ở Bảng 3. 
Bảng 3. Thành phần hóa lý, vi sinh của các sản phẩm khô cá lóc

\begin{tabular}{lrrr}
\hline Chỉ tiêu & Mẫu nghiên cứu & Mẫu 1 & Mẫu 2 \\
\hline Độ hoạt động của nước & $0,605 \pm 0,02^{\mathrm{a}}$ & $0,612 \pm 0,02^{\mathrm{b}}$ & $0,623 \pm 0,01^{\mathrm{c}}$ \\
Độ ầm (\%) & $20,23 \pm 0,96^{\mathrm{ab}}$ & $18,80 \pm 1,13^{\mathrm{a}}$ & $21,09 \pm 0,82^{\mathrm{b}}$ \\
Protein (\%) & $56,51 \pm 0,28^{\mathrm{a}}$ & $53,56 \pm 0,47^{\mathrm{b}}$ & $51,15 \pm 0,42^{\mathrm{c}}$ \\
Lipid (\%) & $6,21 \pm 0,34^{\mathrm{a}}$ & $5,40 \pm 0,24^{\mathrm{b}}$ & $5,92 \pm 0,28^{\mathrm{ab}}$ \\
$\mathrm{NaCl}(\%)$ & $5,83 \pm 0,23^{\mathrm{a}}$ & $8,25 \pm 0,17^{\mathrm{c}}$ & $7,24 \pm 0,33^{\mathrm{b}}$ \\
Peroxide (meq/kg) & $0,095 \pm 0,004^{\mathrm{a}}$ & $0,157 \pm 0,007^{\mathrm{b}}$ & $0,326 \pm 0,009^{\mathrm{c}}$ \\
Độ màu b* & $3,58 \pm 0,42^{\mathrm{a}}$ & $12,35 \pm 0,36^{\mathrm{c}}$ & $9,85 \pm 0,41^{\mathrm{b}}$ \\
TSVKHK (cfu/g) & $1,5 \times 10^{3}$ & $3,25 \times 10^{5}$ & $1,12 \times 10^{5}$ \\
\hline
\end{tabular}

(Các chũ cái khác nhau trong cùng một hàng biểu thị sụ khác biệt có ý nghĩa của các nghiệm thức khảo sát ở mức độ tin cây $95 \%)$

Hàm lượng protein và lipid là hai chỉ tiêu dinh dưỡng được quan tâm trước tiên cho sản phẩm chế biến từ cá. Bảng 3 cho thấy khô cá lóc nghiên cứu có hàm lượng protein và lipid cao $(56,51 \%$ và $6,21 \%$ ). Tuy nhiên, đối với hai sản phẩm khô cá lóc trên thị trường hàm lượng này thấp hơn, hàm lượng protein đạt $51,15-53,56 \%$ và $5,40-5,92 \%$ đối với lipid. Khi so sánh với sản phẩm tại hai cơ sở, khô cá lóc nghiên cứu có độ ẩm gần như nhau nhưng lại có độ hoạt động của nước thấp hơn, điều này giúp làm tăng hiệu suất thu hồi sản phẩm nhưng vẫn đảm bảo tốt cho quá trình tồn trữ. Hàm lượng muối trong mẫu nghiên cứu tương đối thấp hơn so với hai mẫu còn lại. Nếu sản phẩm nghiên cứu có hàm lượng muối là $5,83 \%$ thì sản phẩm tại hai cơ sở có hàm lượng muối dao động từ $7,24-8,25 \%$. Kết quả này cho thấy các sản phẩm tại các cơ sở được phối trộn với hàm lượng muôi khá cao để kéo dài thời gian bảo quản (giúp hạ $\mathrm{a}_{\mathrm{w}}$ ). Ảnh hưởng của nồng độ chất tan (muối) cao đã làm mất đi mùi vị đặc trưng, khô cá mặn hơn và mất đi mùi thơm cá vốn có của sản phẩm. Ngoài ra, hàm lượng muối bổ sung cao cũng là nguyên nhân làm cho các sản phẩm bị cứng, độ sáng giảm, sản phẩm bị sẫm màu. Ngược lại, đối với mẫu nghiên cứu, muối còn có tác động điều vị, sản phẩm có mùi vị hài hòa, phù hợp với khẩu vị người tiêu dùng. Xét

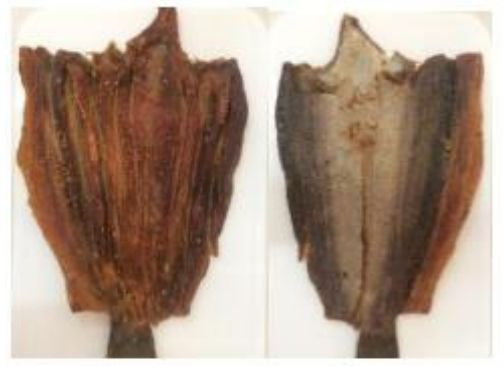

Mẫu cơ sở 1

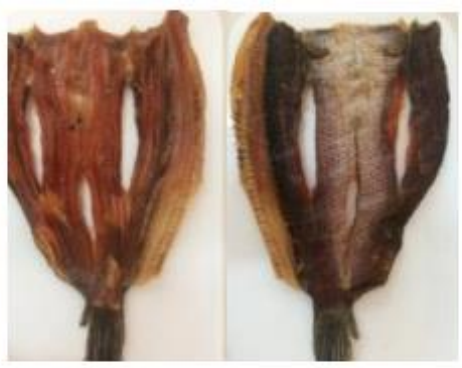

Mẫu cơ sở 2 về các giá trị oxy hóa chất béo, khô cá lóc nghiên cứu có giá trị peroxide thấp $(0,095 \mathrm{mEq} / \mathrm{kg})$, không ảnh hưởng đến mùi vị của sản phẩm, sản phẩm vẫn giữ được màu sắc đẹp, mùi vị đặc trưng của khô cá lóc. Bên cạnh đó, hai sản phẩm của hai cơ sở cũng được đánh giá chỉ tiêu này, đối với mẫu cơ sở 1 có giá trị peroxide là $0,157 \mathrm{mEq} / \mathrm{kg}$ lipid, mẫu cơ sở 2 là $0,326 \mathrm{mEq} / \mathrm{kg}$. Với hàm lượng này, chất lượng của các sản phẩm tại hai cơ sở vẫn được chấp nhận. Chỉ tiêu vi sinh được quan tâm nhiều nhất đối với tồn trữ sản phẩm, kết quả phân tích tổng vi khuẩn hiếu khí (TVKHK) của mẫu nghiên cứu là $1,5 \times 10^{3}$ (cfu/g) - đảm bảo TCVN 10734:2015. Tuy nhiên, đối với mẫu thị trường 1 lẫn cả cơ sở 2 đều có giá trị lần lượt là $3,25 \times 10^{5}$ và $1,12 \times 10^{5} \mathrm{cfu} / \mathrm{g}$. Qua đó cho thấy quy trình sản xuất của mẫu nghiên cứu đảm bảo điều kiện vệ sinh cũng như điều kiện bảo quản tốt, ngăn cản sự phát triển của vi sinh.

\subsection{2. Đánh giá cảm quan các sản phẩm khô cá lóc}

Đặc điểm bề ngoài của khô đối với 2 chỉ tiêu cảm quan về tạp chất và côn trùng, tất cả các mẫu đều đáp ứng (Hình 4), do đó phân tích cảm quan chỉ tập trung các chỉ tiêu về màu sắc, mùi vị, trạng thái.

Hình 4. Các sản phẩm khô cá lóc có độ ẩm trung bình $\mathbf{2 0 \%}$

Phương pháp thử các chỉ tiêu cảm quan từ TCVN 10734: 2015 được đề nghị thực hiện theo
TCVN 5277:1990, với mỗi chỉ tiêu có hệ số quan trọng khác nhau và giá trị hệ số quan trong được tiến 
hành khảo sát dựa trên 7 cảm quan viên và kết quả cho thấy rằng, chỉ tiêu trạng thái được xem là quan trọng nhất, kế đến là chỉ tiêu mùi và vị, cuối cùng là chỉ tiêu màu sắc. Kết quả của quá trình đánh giá được thể hiện tại Bảng 4.

Bảng 4. Kết quả đánh giá cảm quan so sánh giữa mẫu nghiên cứu với hai mẫu hiện có trên thị trường theo quy định của TCVN 10734:2015

\begin{tabular}{lrrr}
\hline Mẫu & Mẫu nghiên cứu & Mẫu 1 & Mẫu 2 \\
\hline Màu & $2,14 \pm 0,38^{\mathrm{a}}$ & $1,22 \pm 0,27^{\mathrm{b}}$ & $2,00 \pm 0,29^{\mathrm{a}}$ \\
Mùi & $3,86 \pm 0,38^{\mathrm{a}}$ & $2,86 \pm 0,69^{\mathrm{b}}$ & $3,86 \pm 0,69^{\mathrm{a}}$ \\
Vị & $4,14 \pm 0,38^{\mathrm{a}}$ & $2,43 \pm 1,13^{\mathrm{b}}$ & $3,29 \pm 1,13^{\mathrm{a}}$ \\
Trạng thái & $6,44 \pm 1,13^{\mathrm{a}}$ & $4,50 \pm 0,87^{\mathrm{b}}$ & $5,15 \pm 0,87^{\mathrm{b}}$ \\
\hline Tồng & 16,59 & 11,01 & 14,30 \\
\hline
\end{tabular}

(Ghi chú: Dựa trên điểm trung bình có trọng luợng, với hệ số quan trọng của màu là 0,5 , mùi và vị là 1 , trạng thái 1,5 ;

Các chũ cái khác nhau trong cùng một hàng biểu thị sụ khác biệt có ý nghĩa của các nghiệm thức khảo sát ở múc độ tin cậy 95\%)

Bảng 4 cho thấy mẫu nghiên cứu được đánh giá vượt trội hơn so với cả hai mẫu trên thị trường, đặc biệt là đối với mẫu 1 . Điều đó được thể hiện thông qua tổng điểm trung bình có trọng lượng của mẫu nghiên cứu là 16,59 có sự chênh lệch đáng kể so với mẫu thị trường 1 là 11,01 đồng thời cũng lớn hơn so với mẫu cơ sở 2 là 14,30.

Bên cạnh dựa trên kết quả cho điểm của các cảm quan viên, theo đóng góp cũng như nhận xét của các cảm quan viên về các mẫu đánh giá như sau: mẫu khô cá thị trường 1 được đánh giá là có màu khá sậm, vị hơi mặn và cấu trúc khá cứng, đồng thời sản phẩm có mùi hơi hăng do ảnh hưởng của quá trình oxy hóa chất béo. Trong khi đó, mẫu khô cá tại cơ sở 2 lại có màu nâu hơi đỏ, hậu vị chấp nhận nhưng cấu trúc hơi cứng. Ngược lại, mẫu nghiên cứu được đánh giá có màu vàng tự nhiên, vị ngọt đạm, mùi thơm khô, cấu trúc vừa ăn không bị quá cứng. Điều này lại một lần nữa cho thấy sự chấp nhận cũng như sức cạnh tranh của sản phẩm nghiên cứu trên thị trường thực phẩm. Ngoài ra, việc này còn cho thấy tầm quan trọng của việc kiểm soát cũng như điều kiện vệ sinh và bảo quản sản phẩm. Với nguyên liệu kém chất lượng kết hợp với điều kiện phơi sấy không đạt yêu cầu có thể là những nguyên nhân gây ra các thuộc tính không mong muốn cho sản phẩm.

Để giúp dễ hình dung hơn sự khác biệt giữa ba mẫu, kết quả đánh giá cảm quan ba mẫu khô cá lóc được xử lý bằng phương pháp QDA dựa trên điểm trung bình, thể hiện ở Hình 5 .

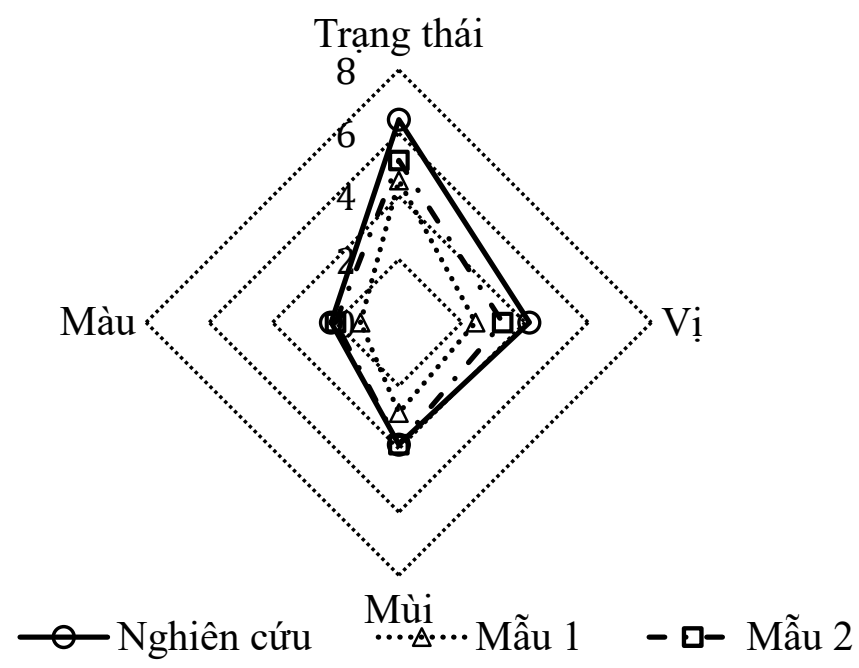

Hình 5. Đồ thị thể hiện điểm cảm quan của các sản phẩm khô cá lóc

Kết quả cho thấy hai mẫu khô cá thị trường đều có giá trị cảm quan thấp hơn mẫu nghiên cứu. Điều này có lẽ do các mẫu thị trường chưa được nghiên cứu kỹ về hàm lượng gia vị và phụ gia bổ sung, công thức tẩm ướp chủ yếu dựa vào kinh nghiệm nên chất lượng sản phẩm chưa được ổn định. Ngược lại, mẫu 
khô cá nghiên cứu luôn được kiểm soát chất lượng từ nguyên liệu cho đến khi thành phẩm, do đó sản phẩm được đánh giá cao cả về mùi vị, màu sắc và trạng thái.
Kết quả đánh giá thị hiếu trên 50 người tiêu dùng, sử dụng thang điểm ưa thích Hedonic được biểu hiện ở Hình 6 cho thấy, mẫu nghiên cứu có phổ điểm từ 6 đến 9 , mẫu cơ sở 1 dao động từ 4 đến 8 và mẫu cơ sở 2 từ 2 đến 7.

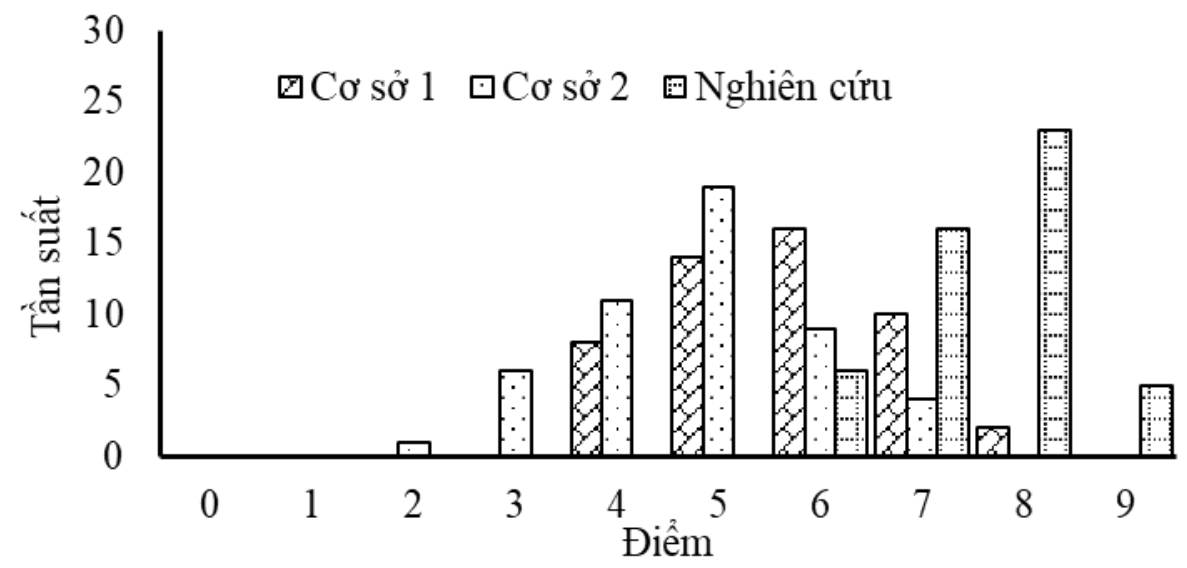

Hình 6. Đồ thị tần suất điểm ưa thích của từng loại khô cá lóc theo thang điểm Hedonic

Đồng thời, kết quả thống kê sở thích người tiêu dùng theo thang điểm Hedonic ở Bảng 5 đã một lần nữa khẳng định có sự khác biệt rõ rệt về độ ưa thích giữa các loại khô cá. Nhìn chung, khô cá lóc nghiên cứu được người tiêu dùng ưa thích nhất với điểm trung bình cao và khác biệt ý nghĩa so với hai mẫu còn lại. Mẫu khô của cơ sở 1 có điểm ưa thích cao hơn mẫu khô của cơ sở 2 nhưng vẫn nằm ở mức trung bình (không thích, không chán). Tóm lại, sản phẩm khô cá lóc nghiên cứu cho chất lượng cảm quan cao, thích hợp với thị hiếu người tiêu dùng.

\section{Bảng 5. Điểm ưa thích trung bình của các loại} khô cá lóc

\begin{tabular}{lr}
\hline Khô cá lóc & Điểm ưa thích \\
\hline Mẫu nghiên cứu & $7,54 \pm 0,91^{\mathrm{a}}$ \\
Mẫu cơ sở 1 & $5,68 \pm 1,13^{\mathrm{b}}$ \\
Mẫu cơ sở 2 & $4,82 \pm 1,26^{\mathrm{c}}$ \\
\hline
\end{tabular}

(Các chũ cái khác nhau trong cùng một cột biểu thị sụ khác biệt có ý nghĩa của các nghiệm thức khảo sát ở mức độ tin cậy 95\%)

\section{KẾT LUẬN}

Kết quả nghiên cứu cho thấy việc sử dụng các biện pháp kết hợp rào cản hữu hiệu hạn chế sự oxy hóa có hiệu quả tích cực trong việc kéo kéo dài thời gian bảo quản, đảm bảo chất lượng và an toàn vệ sinh thực phẩm. Sản phẩm đảm bảo an toàn về chỉ tiêu vi sinh, kim loại nặng và độ hoạt động của nước giữ ở mức thấp hơn 0,70 sau 12 tuần bảo quản ở nhiệt độ phòng $\left(28-30^{\circ} \mathrm{C}\right), 32$ tuần bảo quản ở nhiệt độ lạnh $\left(0-4^{\circ} \mathrm{C}\right)$ và 48 tuần trữ đông $\left(-18\right.$ đến $\left.-20^{\circ} \mathrm{C}\right)$ khi bảo quản bằng bao bì $\mathrm{PA}$, độ chân không $80 \%$. Sản phẩm khô cá lóc có chất lượng ổn định và cảm quan cao hơn sản phẩm thị trường, đồng thời đáp ứng chất lượng theo TCVN 5649:2006 và TCVN 10734:2015.

\section{TÀI LIÊU THAM KHẢO}

Abbas., K. A., Saleh, A. M., A. Mohamed, A. \& Lasekan, O. (2009). The relationship between water activity and fish spoilage during cold storage: A review. Journal of Food, Agriculture \& Environment, 7(3\&4), 86-90.

Akintola, S.L., Ayodele, B., Abubakar, B., Oluwafemi, D. O. \& Beatrice, O. B. (2013). Effects of Hot Smoking and Sun Drying Processes on Nutritional Composition of Giant Tiger Shrimp (Penaeus monodon, Fabricius, 1798). Pol. J. Food Nutr. Sci., 63(4), 227-237.

Barden., L. M. (2004). Understanding Lipid Oxidation in Low-Moisture Food. Doctoral Dissertations. University of Massachusetts Amherst, US, 155pp.

Bộ Khoa học và Công nghệ. (2008). Tiêu chuẩn Việt Nam về Thuỷ sản khô-Yêu cầu vệ sinh (TCVN 5649: 2006). https://tieuchuan.vsqi.gov.vn/tieuchuan/view?soh ieu=TCVN+5649\%3A2006.

Bộ Khoa học và Công nghệ. (2015). Tiêu chuẩn quốc gia về Thủy sản khô - Yêu cầu kỹ thuật (TCVN 10734: 2015).

https://tieuchuan.vsqi.gov.vn/tieuchuan/view?soh ieu $=\mathrm{TCVN}+10734 \% 3 \mathrm{~A} 2015$.

Bộ Khoa học và Công nghệ. (2018). Tiêu chuẩn Việt Nam về thủy sản - Phuoong pháp xác định hàm lượng 
nước (TCVN 3700 - 90).

https://tieuchuan.vsqi.gov.vn/tieuchuan/view?sohieu $=\mathrm{TCVN}+3700 \% 3 \mathrm{~A} 1990$.

Bộ Khoa học và Công nghệ. (2020). Tiêu chuẩn Việt Nam về thủy sản - Phuoong pháp xác định hàm luọng nito ammoniac (TCVN 3706:1990). https://tieuchuan.vsqi.gov.vn/tieuchuan/view?sohie $\mathrm{u}=\mathrm{TCVN}+3706 \% 3 \mathrm{~A} 1990$.

Ceballos, M. J. (2012). Effect of protein and lipid oxidation in the changes of color in salted and dried herring and klippfish. Master thesis. Norwegian University of Science and Technology. Trondheim, Norway, 84 pp.

Esener., A. A., Bol., G., Kossen., N. W. F. \& Roels J. A. (1981). Effect of water activity on microbial growth. Proceedings of the Sixth International Fermentation Symposium Held in London, Canada, July 20-25, 1980. Scientific and Engineering Principles, 339-344.

Hồ Mỹ Hạnh \& Bùi Minh Tâm. (2015). Đặc điểm hình thái phân loại và định danh cá chành dục phân bố ở tỉnh Hậu Giang. Tạp chí khoa học truòng Đại hoc Cần Tho, 38(1), 27-34.

Kapsalis, J. G. (1981). Moisture sorption hysteresis. In water activity: Influences on Food Quality. Eds. Rockland L.B. \& Stewart, G.F. Academic Press New York, pp 143-177

Kilic., A (2009). Low temperature and high velocity (LTHV) application in drying: characteristics and effects on the fish quality. Journal of Food Engineering, 91(1),173.

Lê Xuân Sinh \& Đỗ Minh Chung. (2010). Hiện trạng và những thách thức cho nghề nuôi cá lóc (Channa micropeltes và Channa striatus) ở Đồng bằng sông Cửu Long. Tạp chí Nông nghiệp và phát triển nông thôn, 2, 436-447

Nguyễn Văn Mười \& Trần Thanh Trúc. (2016). Ảnh hưởng của việc điều khiển độ hoạt động của nước đến chất lượng khô từ cá lóc nuôi tại tỉnh
Đồng Tháp. Tạp chi khoa học trường Đại học Cần Tho, Nông nghiệp, 92-97.

DOI:10.22144/ctu.jsi.2016.026

Potter, N. N. \& Hotchkiss. J. H (1995). Food science. Food science texts series. 5 th ed. New York: Chapman \& Hall.

Theodore, P. L. \& Altunakar, B. (2008). Water Activity Prediction and Moisture Sorption Isotherms. In book: Water Activity in Foods: Fundamentals and Applications. Editor(s): Gustavo V., Barbosa-Cánovas., Anthony. J., Fontana Jr. Shelly J. S., Theodore P. L. Food Science and Nutrition, 109-154. DOI: 10.1002/9781118765982.ch7

Tran Bach Long, Tran Thanh Truc \& Nguyen Van Muoi. (2017). Characteristics and Rigor Mortis Changes of Snakehead Fish (Channa striata) Cultivated in the Mekong Delta. Food Science and Technology: integration for ASEAN Economic Community Sustainable Development. Proceedings of the 15th ASEAN Conference on Food Science and Technology. November 14-17, 2017 Ho Chi Minh City, Viet Nam. Volume 3, 399-404.

Trần Bạch Long, Trần Thanh Trúc \& Nguyễn Văn Mười. (2019). Ảnh hưởng của ướp muối đến sự oxy hóa lipid và oxy hóa protein trong cơ thịt cá lóc (Channa striata) nuôi. Tạp chí Khoa học Truòng Đại hoc Cần Tho, 55 (Công nghệ sinh hoc), 301-310. DOI:10.22144/ctu.jsi.2019.074

Trần Bạch Long, Trần Thanh Trúc \& Nguyễn Văn Mười (2020). Sự oxy hóa và đặc tính chất lượng cơ thịt cá lóc nuôi ở các giai đoạn biến đổi sinh hóa. Tạp chi Khoa hoc Công nghệ Nông nghiệp Việt Nam, 6(115), 129-136.

Villanueva, N. \& Da Silva, M.A. A. P. (2009). Comparative performance of the nine-point hedonic, hybrid and self-adjusting scales in the generation of internal preference maps. Food Quality and Preference, 20, 1-12. 